\title{
Pola Terapi pada Faktor Risiko Kardioserebrovaskuler Pasien Penyakit Ginjal Kronis yang Menjalani
} Hemodialisis

Rizaldy Taslim Pinzon, Martinus Bagas Hogantara Padmanaba*, Esdras Ardi Pramudita, Sugianto

Fakultas Kedokteran, Universitas Kristen Duta Wacana, Yogyakarta

*Corresponding author: bagashogantara@gmail.com

Submitted: 2 Mei 2019

Accepted: 24 Juli 2019

Published online: 31 Juli 2019

\begin{abstract}
Background: Chronic kidney disease (CKD) is a progressive decrease in kidney function. The treatment of CKD varies greatly because CKD has many risk factors such as cardiocerebrovascular disease. Appropriate treatment should be given for underlying disease. Objective: To identify the profil of treatment for risk factors for cardiocerebrovascular disease in chronic kidney disease patients undergo hemodialysis. Methods: This study used cross sectional method with a descriptive approach. The subjects studied were patients with chronic kidney disease who underwent hemodialysis at Bethesda Hospital and Panti Rapih Hospital Yogyakarta. The data used in this study is secondary data taken from medical record data. The data were shown in tables for analysis. Results: This study involved 92 chronic kidney disease of patients with hemodialysis consist of 60 men (65.2\%) and 32 women (35.8\%) with the mean of age is 50 years old. Patients with a clinical history who were at risk of becoming cardiocerebrovascular disease and had not received treatment 39 people (42.4\%). The major risk factor of cardiocerebrovascular disease was hyperhomocystein 91 patients (98.9\%). The common medication used to reduce the occurrence of cardiocerebrovascular disease were folic acid with a total of 81 patients (89\%), anti anemia 77 patients (90.6\%), anti hypertensive 74 patients $(90.2 \%)$. Conclusions: The common medication used were folic acid, anti anemia, and anti hypertensive. The most common cardiocerebrovascular risk factor was hyperhomocysteinemia.
\end{abstract}

Keywords: treatment, chronic kidney disease, cardioserebrovascular

\begin{abstract}
Abstrak
Pendahuluan: Penyakit ginjal kronis (PGK) merupakan penurunan fungsi ginjal secara progresif dan sudah berlangsung lama. Pola terapi pada PGK sangat bervariasi karena PGK memiliki banyak faktor risiko seperti penyakit kardioserebrovaskular sehingga perlu diberikan obat yang sesuai dengan penyakit yang mendasari. Tujuan: Mengidentifikasi profil pola terapi pada faktor risiko penyakit kardioserebrovaskular pasien penyakit ginjal kronis yang menjalani hemodialisis. Metode: Penelitian ini menggunakan rancangan penelitian cross sectional atau potong lintang dengan pendekatan deskriptif. Subjek yang diteliti adalah penderita penyakit Ginjal Kronis yang menjalani hemodialisis di RS Bethesda dan RS Panti Rapih Yogyakarta. Data yang digunakan dalam penelitian ini merupakan data sekunder yang diambil dari data rekam medis. Analisis menggunakan data yang diambil dibuat dalam bentuk tabel. Hasil: Penelitian ini melibatkan 92 pasien penyakit ginjal kronis yang menjalani hemodialisis terdiri dari 60 laki-laki $(65,2 \%)$ dan 32 perempuan $(34,8 \%)$ dengan rata-rata usia 50 tahun. Pasien dengan riwayat klinis yang berisiko menjadi penyakit kardioserebrovaskular dan belum mendapat pengobatan 39 orang $(42,4 \%)$. Faktor risiko kardioserebrovaskular paling banyak adalah hiperhomosisteinemia 91 pasien $(98,9 \%)$. Obat yang banyak digunakan untuk mengurangi terjadinya penyakit kardioserebrovaskular adalah asam folat dengan jumlah 81 pasien (89\%), anti anemia 77 pasien (90,6\%), dan anti hipertensi 74 pasien $(90,2 \%)$. Kesimpulan: Pola terapi yang banyak digunakan adalah asam folat, anti anemia, dan anti hipertensi. Faktor risiko kardioserebrovaskular paling banyak adalah hiperhomosisteinemia.
\end{abstract}

Kata kunci: pola terapi, penyakit ginjal kronis, kardioserebrovaskular 


\section{PENDAHULUAN}

Berdasarkan data Riset Kesehatan Dasar (Riskesdas) tahun 2013 menunjukkan bahwa prevalensi penduduk Indonesia yang menderita gagal ginjal sebesar $0,2 \%$ atau 2 per 1000 penduduk. Prevalensi PGK di Yogyakarta adalah 0,2\% atau 2 per 1000 penduduk (Kemenkes RI, 2017).

Penyakit ginjal kronis merupakan kelainan fungsi atau struktur ginjal yang berlangsung lebih dari 3 bulan yang ditandai dengan adanya satu atau lebih tanda kerusakan ginjal disertai penurunan LFG (KDIGO, 2013).

Penyakit ginjal kronis dapat menimbulkan beberapa komplikasi yaitu anemia, hiperlipidemia, osteofistrofi, masalah nutrisi dan penyakit kardioserebrovaskular. Pasien penyakit ginjal kronis memiliki risiko 5-10 kali lebih tinggi untuk meninggal akibat penyakit kardioserebrovaskular. Penyakit kardioserebrovaskular menjadi komplikasi yang ditakutkan karena merupakan penyebab utama pada penyakit ginjal kronis (Subagio, 2014).

Berdasarkan data yang ada dan mengetahui terapi serta penyakit penyerta pada PGK yang menjalani hemodialisis, Penelitian ini dilakukan untuk mengukur pola terapi pada faktor risiko kardioserebrovaskular pasien penyakit ginjal kronis yang menjalani hemodialisis.

\section{METODE}

Penelitian di lakukan di RS Bethesda dan RS Panti Rapih Yogyakarta pada bulan Agustus 2018 Desember 2019. Metode penelitian yang digunakan yaitu cross-sectional dengan pendekatan deskriptif yang menggunakan rekam medik pasien gagal ginjal kronis yang menjalani hemodialisis. Pengambilan sampel dilakukan secara purposive dari data rekam medik yang memenuhi kriteria inklusi yaitu pasien dengan gagal ginjal yang menjalani hemodialisis, bersedia menjadi responden dan menjalani hemodialisis rutin 2 kali dalam seminggu. Kriteria Ekslusi yaitu pasien yang tidak bersedia menjadi responden dan tidak kompeten dalam memberikan inform consent. Data yang diperoleh disajikan dan dilaporkan dalam bentuk tabel persentase.

\section{HASIL DAN PEMBAHASAN}

Pada penyakit ginjal kronis insiden dan prevalensi tergantung pada jenis kelamin, usia, ras, dan penyakit bawaan. Prevalensi penyakit ginjal kronis dengan jenis kelamin laki-laki lebih banyak daripada perempuan dan meningkat dengan bertambahnya usia (Krauss \& Hak, 2000). Data pada Tabel 1 menunjukkan prevalensi lakilaki lebih banyak yaitu 60 orang $(65,2 \%)$ sedangkan perempuan 32 orang $(34,8 \%)$. Perbedaan jenis kelamin dapat menyebabkan perbedaan pola hidup. Pola hidup seperti merokok, mengonsumsi alkohol yang merupakan faktor risiko terjadinya penyakit ginjal yang ditemukan lebih banyak pada laki-laki dibandingkan perempuan (Chang dkk., 2016). Distribusi usia paling banyak pada rentang 56 tahun sampai 65 tahun yaitu berjumlah 28 orang $(30,4 \%)$. Pada usia lebih dari 40 tahun terjadi penurunan bersihan kreatinin 0,75 mL/menit/tahun (Mallappallil \& Friedman, 2014).

Tabel 1. Karakteristik pasien

\begin{tabular}{lcc}
\hline Karakteristik Pasien & $\mathrm{n}=92$ & $\%$ \\
\hline Usia & 1 & 1,1 \\
17 - 25 tahun & 10 & 10,9 \\
26 - 35 tahun & 17 & 18,5 \\
36 - 45 tahun & 27 & 29,3 \\
46 - 55 tahun & 28 & 30,4 \\
56 - 65 tahun & 9 & 9,8 \\
> 65 tahun & & \\
Jenis Kelamin & 60 & 65,2 \\
Laki-laki & 32 & 34,8 \\
Perempuan & & \\
Faktor Risiko & & \\
Kardioserebrovaskular & 82 & 89,1 \\
Hipertensi & 32 & 34,8 \\
Diabetes Melitus & 85 & 92,4 \\
Anemia & 9 & 9,8 \\
Dislipidemia & 91 & 98,9 \\
Hiperhomosisteinemia & & \\
Pola Terapi & 81 & 88 \\
Asam Folat & 74 & 80,4 \\
Obat Antihipertensi & 22 & 23,9 \\
Obat Antidiabetes & 6 & 6,5 \\
Penurun Lipid & 77 & 83,7 \\
Anti Anemia & & \\
& & \\
\hline
\end{tabular}

Penelitian ini mengungkap penggunaan yang tinggi sebanyak 90,6\% yakni 74 pasien, untuk terapi faktor risiko kardioserebrovaskular. Pasien PGK mempunyai target terapi $<140 / 90 \mathrm{mmHg}$ (Krauss \& Hak, 2000). Data pada Tabel 2 menunjukan obat anti hipertenesi paling banyak golongan calcium channel blocker (CCB) 47 orang. Terapi dengan golongan calcium channel blocker digunakan sebagai terapi tunggal atau terapi kombinasi. Golongan CCB merupakan antihipertensi yang efektif pada PGK (KDOQI, 2012). Pada pasien yang intoleran CCB, golongan angiotensin reseptor blocker diyakini mampu berfungsi sebagai renoprotektif lebih baik 
dibandingkan dengan golongan lain (Carter \& Barry, 2002).

Data pada Tabel 2 menunjukkan obat golongan diuretik digunakan pada penelitian ini yaitu Furosemid 34 orang. Penggunaan obat diuretik dapat mengatasi udema terkait dengan gagal jantung kongestif. Obat furosemide menghambat reabsorbsi natrium dan klorida pada tubulus proksimal, distal, dan loop of henle.

Penggunaan beta blocker dapat memperburuk fungsi ginjal karena penurunan aliran darah ginjal (Nafrialdi, 2007). Data pada Tabel 2 menunjukkan 8 orang $(8,7 \%)$ menggunakan golongan beta blocker yaitu bisoprolol. Berdasarkan pustaka maka pasien dengan gagal ginjal kronik sebaiknya menghindari penggunaan beta blocker.

Penggunaan alfa 2 adrenergic agonist dapat menurunkan tekanan perfusi (Lewis dkk., 2002). Data pada Tabel 2 menunjukkan 13 pasien mendapatkan terapi Clonidin. Berdasarkan pustaka Penggunaan Alfa 2 adrenergic agonist sebaiknya dihindari karena dapat menyebabkan penurunan LFG.

Tabel 2. Karakteristik golongan obat anti hipertensi

\begin{tabular}{lcc}
\multicolumn{3}{c}{$(\mathrm{n}=74)$} \\
\hline Golongan & $\begin{array}{c}\text { Jumlah } \\
\text { Pasien }\end{array}$ & $\%$ \\
\hline CCB & 47 & 63,5 \\
ARB & 41 & 55,4 \\
Diuretik & 34 & 45,9 \\
Alfa 2 Agonis & 13 & 17,6 \\
Beta Blocker & 8 & 10,8 \\
\hline
\end{tabular}

Data pada Tabel 3 menunjukkan penggunaan terapi tunggal untuk antihipertensi sebanyak 26 dan terapi kombinasi sebanyak 48 pasien. Data pada Tabel 4 menununjukkan terapi tunggal yang paling banyak digunakan adalah CCB yakni 13 orang. Data pada Tabel 5 menunjukkan kombinasi obat yang paling banyak digunakan adalah kombinasi 2 yaitu ARB dan Diuretik. Pemberian terapi kombinasi dapat meningkatkan efektivitas obat sehingga target penurunan pada pasien hipertensi dapat tercapai (Untari dkk., 2014).

Tabel 3. Karakteristik terapi hipertensi $(n=74)$

\begin{tabular}{ccc}
\hline Jenis & Jumlah & $\%$ \\
Terapi & Pasien & \\
\hline Tunggal & 26 & 35,1 \\
Kombinasi & 48 & 64,9 \\
\hline
\end{tabular}

Tabel 4. Karakteristik terapi tunggal hipertensi

\begin{tabular}{lcc}
\multicolumn{3}{c}{$(\mathrm{n}=26)$} \\
\hline \multicolumn{1}{c}{ Golongan } & $\begin{array}{c}\text { Jumlah } \\
\text { Pasien }\end{array}$ & $\%$ \\
\hline CCB & 13 & 17,6 \\
ARB & 7 & 9,5 \\
Diuretik & 4 & 5,4 \\
Alfa 2 Agonis & 2 & 2,7 \\
\hline
\end{tabular}

Tabel 5. Terapi kombinasi anti hipertensi $(n=48)$

\begin{tabular}{lcc}
\hline Golongan & $\begin{array}{c}\text { Jumlah } \\
\text { Pasien }\end{array}$ & $\%$ \\
\hline Kombinasi 2 Obat & 3 & 4,1 \\
CCB, Alfa 2 Agonis & 6 & 8,1 \\
CCB, ARB & 9 & 12,2 \\
ARB, Diuretik & 8 & 10,8 \\
CCB, Diuretik & 2 & 2,7 \\
CCB, Beta Blocker & 1 & 1,4 \\
CCB, ARB & 1 & 1,4 \\
Alfa 2 Agonis, Diuretik & & \\
& & \\
Kombinasi 3 Obat & 3 & 4,1 \\
CCB, ARB, Alfa 2 Agonis & 1 & 1,4 \\
ARB, Diuretik, Beta Blocker & 8 & 10,8 \\
Diuretik, CCB, ARB & 2 & 2,7 \\
ARB, CCB, Beta Blocker & & \\
& & \\
Kombinasi 4 Obat & 1 & 1,4 \\
CCB, ARB, Alfa 2 Agonis, & & \\
Diuretik & \\
CCB, ARB, Alfa 2 Agonis, & 1 & 1,4 \\
Beta Blocker & & \\
ARB, Alfa 2 Agonis, Diuretik & 2 & 2,7 \\
Beta Blocker & & \\
\hline
\end{tabular}

Penggunaan asam folat membantu menurunkan risiko hiperhomosisteinemia. Data pada Tabel 6 menunjukkan penggunaan asam folat sebanyak $89 \%$, yakni sejumlah 81 pasien. Pasien dengan PGK stadium akhir memiliki prevalensi hiperhomosistein yang tinggi. Hal ini sesuai dengan pustaka bahwa plasma homosistein berkolerasi dengan estimasi dari LFG. Penurunan LFG hingga $60 \mathrm{ml} / \mathrm{menit}$ dapat menimbulkan hiperhomoterapi sistein. Pada stadium akhir gagal ginjal prevalensi hiperhomosistein mencapai 85 - 100\%. Hiperhomosistein tinggi pada stadium akhir disebabkan oleh penurunan LFG (Guldener, 2006). 
Data pada Tabel 6 menunjukkan pasien yang memiliki riwayat hiperhomosisteinemia tetapi belum mendapat asam folat tercatat 10 orang. Target pemberian terapi terpenuhi apabila homosistein basal < $10 \mathrm{U} \mathrm{mol} / \mathrm{L}$. Penggunaan asam folat $0,5-5 \mathrm{mg} / \mathrm{hari}$ dapat menurunkan homosistein total serum $15 \%-40 \%$ dalam 6 minggu. Konsumsi diet yang mengandung asam folat, vitamin B6, dan vitamin B12 disarankan pada homosistein basal > $10 \mathrm{U} \mathrm{mol} / \mathrm{L}$ (Guldener, 2006).

Penggunaan obat penginduksi eritopoesis pada pasien PGK digunakan dalam panduan tatalaksana anemia. Berbagai evidences menunjukkan bahwa eritropoietin rekombinan (rHEPO) dapat memperbaiki parameter hematologi, menurunkan mortalitas dan morbiditas, serta meningkatkan kualitas hidup pasien (Fink, 2002). Data pada Tabel 6 menunjukkan 90,2\%, yakni 77 orang dari 92 orang mendapat terapi epoetin alfa. Pasien yang memiliki riwayat anemia tetapi tidak mendapatkan epoetin alfa tercatat 8 orang. KDOQI (2012) memberi pedoman untuk terapi epoetin digunakan saat terjadi penurunan $\mathrm{Hb}$ atau hematokrit hingga $80 \%$ dari batas normal sehingga pada penelitian ini epoetin alfa sudah diberikan sesuai dengan target untuk mengatasi anemia pada pasien.

Tabel 6. Karakteristik riwayat pengobatan

\begin{tabular}{lccc}
\hline \multicolumn{1}{c}{$\begin{array}{c}\text { Riwayat } \\
\text { Pengobatan }\end{array}$} & $\begin{array}{c}\text { Jumlah } \\
\text { Pasien }\end{array}$ & $\begin{array}{c}\text { Total } \\
\text { Pasien }\end{array}$ & $\%$ \\
\hline $\begin{array}{l}\text { Riwayat klinis } \\
\text { (diobati) }\end{array}$ & & & \\
Hiperhomosisteinemia & 81 & 91 & 89 \\
Hipertensi & 74 & 82 & 90,2 \\
Diabetes Melitus & 22 & 32 & 68,8 \\
Dislipidemia & 6 & 9 & 66,7 \\
Anemia & 77 & 85 & 90,6 \\
& & & \\
Riwayat klinis (belum & & & \\
diobati) & & & \\
Hiperhomosisteinemia & 10 & 91 & 11 \\
Hipertensi & 8 & 82 & 9,8 \\
Diabetes Melitus & 10 & 32 & 31,2 \\
Dislipidemia & 3 & 9 & 33,3 \\
Anemia & 8 & 85 & 9,4 \\
\hline
\end{tabular}

Penggunaan obat antidiabetes untuk menurunkan gula darah pada pasien sehingga risiko komplikasi penyakit kardioserebrovaskular dapat menurun (Lubis, 2014). Terapi anti diabetes yang digunakan adalah obat oral dan insulin. Pengendalian gula darah pada pasien PGK secara insensif akan mencegah progresifitas dan mencegah timbulnya penyulit kardiovaskuler baik pada DM Tipe 1 maupun DM Tipe 2 (Gugun, 2008). Data pada Tabel 7 menunjukkan bahwa insulin digunakan oleh 10 pasien sedangkan 12 pasien menggunakan obat oral. Penggunaan obat antidiabetes disesuaikan dengan kondisi pasien. Insulin merupakan terapi antidiabetes yang telah digunakan secara luas pada pasien DM tipe 2 dengan nefropati (Hendromartono, 2014).

Tabel 7. Terapi anti diabetes $(n=22)$

\begin{tabular}{lcc}
\hline Golongan & $\begin{array}{c}\text { Jumlah } \\
\text { Pasien }\end{array}$ & $\%$ \\
\hline Insulin & 10 & 45,5 \\
Glikuidon & 5 & 22,7 \\
Glimipirid & 2 & 9,1 \\
Alpha Glukosidase Inhibitor & 5 & 22,7 \\
\hline
\end{tabular}

Penggunaan penurun lipid golongan HMGCoA reductase inhibitor seperti lovastatin, pravastatin, simvastatin, fluvastatin banyak disarankan dikarenakan golongan obat ini yang paling efektif untuk pasien yang mengalami peningkatan kadar LDL dan kolesterol total (Krauss \& Hak, 2000). Data pada Tabel 8 menunjukkan penggunaan terbanyak obat dislipidemi adalah simvastatin yaitu 5 pasien dan 1 pasien menggunakan gemfibrozil. Pada rekam medis tercatat 3 pasien yang menderita penyakit klinis belum menerima obat. Penggunaan penurun lipid disarankan jika memiliki riwayat klinis untuk mengurangi risiko penyakit kardioserebrovaskular.

Tabel 8. Terapi penurun lipid $(n=6)$

\begin{tabular}{ccc}
\hline $\begin{array}{c}\text { Golongan } \\
\text { Obat }\end{array}$ & $\begin{array}{c}\text { Jumlah } \\
\text { Pasien }\end{array}$ & $\%$ \\
\hline Simvastatin & 5 & 83,3 \\
Gemfibrozil & 1 & 16,7 \\
\hline
\end{tabular}

\section{KESIMPULAN}

Obat yang banyak digunakan pada faktor risiko kardioserebrovaskular pasien penyakit ginjal kronis yang menjalani hemodialisis adalah asam folat 81 pasien (89\%), anti anemia 77 pasien (90,2\%), dan anti hipertensi 74 pasien $(90,6 \%)$. Faktor risiko kardioserebrovaskular yang paling banyak ditemukan dan hampir ditemui pada setiap pasien yang menjalani hemodialisis adalah hiperhomosisteinemia. Terdapat jumlah yang cukup tinggi dari pasien yang memiliki riwayat klinis tetapi belum menerima obat yaitu lebih dari 40\% (39 dari 92 pasien).

\section{DAFTAR PUSTAKA}

Carter, L. \& Barry, J. S. J. (2002) Hipertension (In: DiPiro, T. J., Talbert, R. L., Yee, G. Pharmacotherapy A Pathophysiologic 
Approach, 5th ed). St Louis: McGraww-Hill Companies.

Chang, P., Chien, L., Lin Y. F., Wu, M. S., Chiu, W. T. \& Chiou, H. Y. (2016). Risk Factors of Gender for Renal Progression in Patients with Early Chronic Kidney Disease. Medicine (Baltimore); 95; 4203.

Fink, J. (2002) Treatment for the Anemia of Chronic Kidney Disease. http://www.medscape.com/viewarticle/445253. Accessed: 5 Desember 2018.

Gugun, A. M. (2008) Hiperhomosisteinemia dan Faktor Risiko Kelainan Vaskuler. Mutiara Medika; 8; 97-105.

Guldener, C. V. (2006) Why is Homocysteine Elevatedin Renal Failure and What Can be Expected from Homocysteine-lowering?. Nephrol Dial Transplant; 21; 1161-1166.

Hendromartono. (2014). Nefropati Diabetik (In: Setiati, S. Buku Ajar Ilmu Penyakit Dalam Jilid 2, 6th ed). Jakarta: Interna Publishing.

KDIGO. (2013) Clinical Practice Guideline for the Evaluation and Management of Chronic Kidney Disease. Kidney International Supplements; 3; $1-50$.

KDOQI. (2012) KDOQI US Commentary on the 2012 KDIGO Clinical Practice Guideline for Management of Blood Pressure in CKD. New York: National Kidney Foundation, Inc.
Krauss, A. G. \& Hak, L. J. (2000) Chronic Renal Disease. Philadelphia: Lippicott William and Wilkins.

Kemenkes RI. (2017). InfoDATIN: Situasi Penyakit Ginjal Kronis. Jakarta: Kemenkes RI.

Lewis, M. J., St Peter, W. L. \& Collin, A. (2002). End Stage Renal Disease. StLouis: McGraw-Hill Companies.

Lubis, H. R. (2014). Penyakit Ginjal Kronik. Jakarta: Interna Publishing.

Mallappallil, M. \& Friedman, E. A. (2014). Chronic Kidney Disease in the Elderly: Evaluation and Management. Clinical Practice; 11; 525-535.

Nafrialdi, S. A. (2007). Farmakologi dan Terapi. Jakarta: Departemen Farmakologi dan Terapeutik FK UI.

Subagio, S. W. (2014). Kejadian Penyakit Kardioserebrovaskular pada Penderita Penyakit Ginjal Kronik Stadium V dengan Diabetes Melitus dan Tanpa Diabetes Melitus. Skripsi; Fakultas Kedokteran Universitas Diponegoro, Semarang.

Untari, M. K., Nugroho, A E. \& Irijanto, F. (2014) Perbandingan Efek Terapi Kombinasi 2 Obat dengan 3 Obat Antihipertensi pada Pasien Hemodialisis. Journal of Management and Pharmacy Practice; 4; 215. 